\title{
Carbon acquisition and growth of Antarctic sea ice diatoms in closed bottle incubations
}

\author{
Markus Gleitz*, Helmut Kukert, Ulf Riebesell, Gerhard S. Dieckmann
}

Alfred Wegener Institute for Polar and Marine Research, Postfach 120161, D-27515 Bremerhaven, Germany

\begin{abstract}
Mixed cultures of 4 polar diatoms regularly found in Antarctic pack ice were grown over $20 \mathrm{~d}$ in closed bottles at high light (200 to $250 \mu \mathrm{mol}$ photons $\mathrm{m}^{-2} \mathrm{~s}^{-1}$ ) and at $0^{\circ} \mathrm{C}$ in order to investigate growth physiology and biomass production under conditions simulating the sea ice habitat during summer. Species tested were: Chaetoceros cf. neogracile, Fragilariopsis cylindrus, Thalassiosira antarctica and Porosira pseudodenticulata. Initially, all species grew exponentially, but exponential growth ceased for $P$ pseudodenticulata and $T$ antarctica after $6 \mathrm{~d}$, for $F$. cylindrus after $8 \mathrm{~d}$, and for $C$. cf. neogracile after $10 \mathrm{~d}$. Slight increases in cell number were observed for all species $2 \mathrm{~d}$ later. Peak biomass amounted to $140 \mu \mathrm{g} \mathrm{chl} \mathrm{a}(850 \mu \mathrm{mol} \text { particulate organic carbon, POC })^{-1}$ At the same time, concentrations of dissolved inorganic carbon (DIC) were reduced by $1000 \mu \mathrm{M}$, oxygen concentrations increased to $1400 \mu \mathrm{M}$, and $\mathrm{pH}$ increased to 10.5. At this stage, a substantial decline in plasma-containing cells was recorded for $F$. cylindrus. $C$. cf. neogracile accounted for $80 \%$, and $C$. cf. neogracile and F. cylindrus accounted for $>95 \%$ of total carbon biomass. The carbon isotope composition of POC (expressed as $\delta^{13} \mathrm{C}$ ) increased from -24 to $-9 \%$ during the experiment. Model calculations showed that diffusive uptake of dissolved $\mathrm{CO}_{2}$ satisfied cellular carbon demand for all species except $P$. pseudodenticulata at $\mathrm{CO}_{2}$ (aq) concentrations $>0.5 \mu \mathrm{M}$, whereas direct $\mathrm{HCO}_{3}$ utilization was observed for $\mathrm{C}$. cf. neogracile below this concentration. Our data confirm that intense photosynthetic carbon assimilation may lead to profound chemical changes in isolated interstitial brine solutions, with significant consequences for sea ice biota. We propose that the capacity to efficiently utilize ambient DIC, possibly mediated by virtue of favorable surface to volume ratios as well as active pathways of inorganic carbon acquisition, favors growth of small diatoms, and may be an important factor driving ice algal species succession during summer blooms. Since only 2 species continued to grow in fresh medium following experimental incubation (C. cf. neogracile and $P$. pseudodenticulata), differential tolerance to chemical variations may influence the seeding potential of ice algae following release into the open water
\end{abstract}

KEY WORDS Antarctica Sea ice microalgae Carbon uptake Growth Dissolved inorganic carbon . $\mathrm{pH} \cdot$ Oxygen

\section{INTRODUCTION}

Studies on the ecophysiology of Antarctic sea ice diatoms have often concerned responses to environmental conditions pertinent to the autumn/winter period, i.e. reduced temperature and light at increased salinities (Palmisano \& Sullivan 1982, Aletsee \& Jahnke 1992, Gleitz \& Thomas 1992). However, productivity of sea ice algae during winter is greatly hindered by adverse environmental conditions, and daily production rates are usually 1 to 2 orders of magnitude lower than rates determined during spring and sum-

•E-mail: mgleitz@awi-bremerhaven.de mer (Garrison \& Buck 1991, Garrison \& Close 1993, Gleitz \& Thomas 1993).

Microbial assemblages in Antarctic pack ice are generally distributed throughout floes as surface (Garrison \& Buck 1991) or internal assemblages (Ackley et al. 1979). Recent investigations have shown that during summer, exchange of dissolved components between the water column and the interstitial brine of intact pack ice may be severely restricted, creating a temporarily isolated system (Gleitz et al. 1995). Influx of components taken up by intense primary productivity may not balance algal consumption, causing shifts in the chemical composition of the brine, which will again backlash on algal growth physiology. 
Several investigators have speculated that biomass and productivity of sea ice assemblages may be controlled by the availability of major nutrients (nitrate, phosphate and silicate), which may fall to very low levels during summer in the Antarctic pack (Clarke \& Ackley 1984, Garrison et al. 1990, Dieckmann et al. 1991). However, depletion of major nutrients will proceed in parallel to other chemical changes, in particular depletion of dissolved inorganic carbon (DIC), accumulation of dissolved oxygen and a substantial increase of $\mathrm{pH}$. This is especially notable since dominant sea ice diatoms have recently been shown to photosynthesize and assimilate carbon even at exhausted nutrient concentrations, depleting DIC concentrations to levels much lower than would be expected from ambient nutrient concentrations (Gleitz et al. 1995, Gleitz et al. 1996). Hence, in addition to restraints placed on algal growth by declining nutrient concentrations, chemical variations related to the carbonate system, oxygen concentrations and/or $\mathrm{pH}$ may control growth and species composition of ice algal assemblages during summer blooms. This hypothesis, however, has so far never been studied systematically.

The aim of the study presented here was to determine the upper limit for growth with respect to DIC, dissolved $\mathrm{CO}_{2}\left[\mathrm{CO}_{2}(\mathrm{aq})\right]$, and $\mathrm{O}_{2}$ concentrations and $\mathrm{pH}$ for 4 Antarctic sea ice diatoms in a completely isolated system. Secondly, we wanted to test if there were species-specific differences concerning the capacity to assimilate DIC under such isolated conditions. Additionally, we monitored changes in the ${ }^{12} \mathrm{C} /{ }^{13} \mathrm{C}$ composition of the biomass produced, and asked if growth in a closed system could adversely affect cell integrity to such an extent as to prevent recolonization of the water column following ice melt.

\section{MATERIALS AND METHODS}

Culture material and experimental set up. The diatoms Fragilariopsis cylindrus [surface equivalent cell radius (SER) $1.7 \mu \mathrm{m}$ ], Thalassiosira antarctica (SER $16.9 \mu \mathrm{m}$ ), Porosira pseudodenticulata (SER $35.5 \mu \mathrm{m}$ ) and Chaetoceros cf. neogracile (SER $3.2 \mu \mathrm{m}$ ) were isolated from Weddell Sea surface water and were subsequently grown in unialgal cultures in double-filtered $(0.2 \mu \mathrm{m})$, nutrient-enriched Antarctic seawater at $0^{\circ} \mathrm{C}$ in the home laboratory. Prior to the experiments, stock cultures (not axenic) were grown at $0^{\circ} \mathrm{C}, 200 \mu \mathrm{mol}$ photons $\mathrm{m}^{-2} \mathrm{~s}^{-1}$ (continuous light) in 31 of double-filtered Antarctic seawater enriched with nutrients according to Von Stosch \& Drebes (1964), resulting in nitrate, silicate and phosphate concentrations of roughly 500,200 and $30 \mu \mathrm{M}$ respectively. These concentrations ensured that nutrient limitation would not influence growth performance of the algae. Aliquots equivalent to $5 \mathrm{\mu g} \mathrm{chl}$ a $(800$ to $1800 \mathrm{ml}$ ) were withdrawn from each stock culture during early logarithmic growth, and diluted in fresh, nutrientenriched medium to a final volume of $20 \mathrm{l}$, resulting in an initial chl a concentration of $1 \mu \mathrm{g} \mathrm{l}^{-1}(0.25 \mu \mathrm{g} \mathrm{chl} \mathrm{a}$ $\mathrm{l}^{-1}$ of each species). The suspension was mixed and a subsample was taken for $t_{0}$ (time zero) analyses. The culture was then filled into 20 borosilicate glass bottles (ca $600 \mathrm{ml}$ ), stoppered without air space above the liquid, and incubated for 2 to $20 \mathrm{~d}$ in a temperaturecontrolled incubator at conditions specified above for stock cultures. A continuous irradiance of $200 \mu \mathrm{mol}$ photons $\mathrm{m}^{-2} \mathrm{~s}^{-1}$ ensured that photosynthetic rates would be light-saturated all day long, which we consider a realistic approximation of summer conditions in the high Antarctic (e.g. Gleitz et al. 1996). In order to test if self-shading influenced growth rates, light intensity was increased to $250 \mathrm{\mu mol}$ photons $\mathrm{m}^{2} \mathrm{~s}^{1}$ at $t_{14}$. Every $2 d, 2$ bottles were randomly withdrawn for chemical analyses, $\delta^{13} \mathrm{C}$, particulate organic carbon (POC) and chl a determinations and cell counts. Bottles were shaken prior to sampling and once per day. Aliquots $(10 \mathrm{ml})$ were taken from $t_{20}$ bottles, resuspended in fresh media (3 l), and incubated for another $10 \mathrm{~d}$ under experimental light and temperature conditions in open bottles in order to test the capacity of the algae to grow following experimental exposure.

Determinations of cell number, $\mathrm{chl} a, \delta^{13} \mathrm{C}$ and POC. Subsamples $(25 \mathrm{ml})$ were fixed with acidified Lugol solution, and cell numbers were determined with a Zeiss IM 35 inverted microscope using the Utermöhl method (Utermöhl 1958). About 100 to 300 cells of Porosira pseudodenticulata and Thalassiosira antarctica respectively were enumerated at a magnification of $63 x$, and the entire chamber was counted once. The other 2 species were counted at a magnification of $400 \times$, and 4 strips were counted, each with 200 to 500 cells of each species (cell numbers were initially lower in the resuspension cultures). Growth rates were calculated by optimizing linear regressions in semilogarithmic plots of cell number vs time.

Subsamples of 50 to $1000 \mathrm{~mL}$ were filtered on precombusted $\left(5 \mathrm{~h}\right.$ at $450^{\circ} \mathrm{C}$ ) glass fiber filters for chl $a$ and POC determinations, and frozen at $-27^{\circ} \mathrm{C}$. Chl a was determined fluorometrically after homogenization and $4 \mathrm{~h}$ extraction in $90 \%$ acetone at $4^{\circ} \mathrm{C}$ in the dark (Evans et al. 1987). Prior to POC determinations, filters were exposed to fuming hydrochloric acid for $15 \mathrm{~min}$ and dried overnight at $60^{\circ} \mathrm{C}$. They were then transferred into tin vials, and analyzed using a combination gas chromatograph/mass spectrometer (ANCA-SL 20-20, Europa Scientific). Isotopic composition of $\mathrm{POC}$ is reported in $\delta$-notation relative to PeeDee belemnite $(\mathrm{PDB})$ : 


$$
\delta^{13} \mathrm{C}=\left(\frac{\left.\left[{ }^{13} \mathrm{C}\right] / \mathrm{I}^{12} \mathrm{C}\right]_{\text {sample }}}{\left[{ }^{13} \mathrm{C}\right] /\left[{ }^{12} \mathrm{C}\right]_{\mathrm{PDB}}}-1\right) \times 1000
$$

For the calculation of $\delta^{13} \mathrm{C}_{\text {DIC }}$ at different measuring intervals ( $t_{t}=2$ to 20 ), we used a $\delta^{13} \mathrm{C}_{\text {DIC }}$ at $t_{0}$ of $1.5 \%$, a value determined for surface seawater at $60^{\circ} \mathrm{S}$ (Rau et al. 1982), and assumed the same $\delta^{13} \mathrm{C}$ value for DOC (not measured) as for POC:

$$
\delta^{13} \mathrm{C}_{\mathrm{DIC}_{t_{2}}}=\frac{\delta^{13} \mathrm{C}_{\mathrm{DIC}_{t_{0}}}-\delta^{13} \mathrm{C}_{\mathrm{POC}_{t_{1}}} \times f^{\prime \prime}}{f^{1}}
$$

where

$$
\begin{aligned}
f^{\prime} & =\frac{\left|\mathrm{DIC}_{t_{t}}\right|}{\left[\mathrm{DIC}_{t_{0}}\right]} \\
f^{\prime \prime} & =\frac{\Delta[\mathrm{DIC}]}{\left[\mathrm{DIC}_{t_{0}}\right]} \\
\Delta[\mathrm{DIC}] & =[\mathrm{DIC}]_{t_{0}}-[\mathrm{DIC}]_{t_{1}}
\end{aligned}
$$

Chemical analyses. Initially, 4 volume-calibrated glass bottles $(60 \mathrm{ml})$ were filled, and 2 of these were used for determination of oxygen concentrations according to the Winkler method (Grasshoff 1983). The other 2 bottles were stored and allowed to warm to $15^{\circ} \mathrm{C}$ for $\mathrm{pH}$ determinations. The $\mathrm{pH}$ meter was calibrated daily prior to the measurements with NBS buffers 6.865 and 9.180. After calibration, a combination electrode was immersed in an aliquot of sample water for $2 \mathrm{~h}$. Thereafter, the electrode was immersed in the (previously stoppered) sample, and a stable $\mathrm{pH}$ reading (drift $<0.1 \mathrm{mV} 30 \mathrm{~s}^{-1}$ ) was recorded.

Concentrations of DIC were calculated from measurements of $\mathrm{pH}$ and total alkalinity (TA). TA was determined using a potentiometric titration method (Almgren et al. 1983) at $t_{0,} t_{14}$ and $t_{20}$. For these analyses, the $\mathrm{pH}$ meter was calibrated with NBS buffers 4.001 and 6.865 . A subsample $(50 \mathrm{ml})$ was titrated with hydrochloric acid $(0.035 \mathrm{~N})$, the normality of which had been determined beforehand by iodometric titration. No change of TA was observed between $t_{14}$ and $t_{20}$. and this value was also used for $t_{16}$ and $t_{18}$ determinations. For sampling dates $t_{2}$ to $t_{12}$. TA was raised in accord with PON concentrations (assumed to equal nitrate removal) in the media. The second equivalence point of carbonic acid was calculated by linear regression analyses of Gran plots constructed from 18 to $26 \mathrm{pH}$ measurements in the range of $\mathrm{pH} 4$ to 3 , determined by adding $0.1 \mathrm{ml}$ increments of acid and recording $\mathrm{pH}$. The carbonate system was calculated using the carbonic acid dissociation constants of Mehrbach et al (1973). In situ $\mathrm{pH}$ was calculated from DIC and TA at a temperuture of $0^{\circ} \mathrm{C}$.

Testing for the source of inorganic carbon. In order to test for the source of inorganic carbon utilized during photosynthesis, photosynthetic carbon uptake
$\left(U_{\text {DIC }}\right)$ for each species, determined from carbon quota and instantaneous growth rate, was compared with the potential maximum flux of $\mathrm{CO}_{2}(\mathrm{aq})$ to the cell surface $\left(Q_{d}\right)$ for consecutive measuring intervals, the latter calculated according to (Riebesell et al. 1993):

$$
Q_{a}=4 \pi r D\left(1+r \cdot \frac{k^{\prime}}{D}\right)\left(c_{\infty}-c_{r}\right)
$$

where $r$ is the (surface equivalent) cell radius, $D$ the diffusivity of $\mathrm{CO}_{2}(\mathrm{aq}), k^{\prime}$ the rate constant for conversion of $\mathrm{HCO}_{3}^{-}$to $\mathrm{CO}_{2}(\mathrm{aq})$, assuming that $\mathrm{HCO}_{3}{ }^{-}$conversion is purely chemical, $c_{\infty}$ the $\mathrm{CO}_{2}(\mathrm{aq})$ concentration in the bulk medium, and $c_{r}$ the $\mathrm{CO}_{2}(\mathrm{aq})$ concentration at the cell surface (here assumed to equal zero to allow for maximum flux). If $U_{D I C} / Q_{c} \leq 1$, cellular carbon demand is less than diffusive $\mathrm{CO}_{2}(\mathrm{aq})$ transport can supply, and photosynthetic carbon uptake can rely on $\mathrm{CO}_{2}(\mathrm{aq})$ as the only source of inorganic carbon. If $U_{\mathrm{DIC}} / Q_{\vec{a}}>1$, carbon demand exceeds the potential maximum flux of $\mathrm{CO}_{2}(\mathrm{aq})$, which we consider as evidence for direct use of $\mathrm{HCO}_{3}{ }^{-}$.

\section{RESULTS}

\section{Cell counts and biomass production}

All 4 species grew exponentially during the early phase of the experiment with growth rates of 0.64 , $0.60,0.49$ and $0.32 \mathrm{~d}^{-1}$ for Chaetoceros cf. neogracile, Fragilariopsis cylindrus, Porosira pseudodenticulata and Thalassiosira antarctica respectively (Fig, 1). Exponential growth was maintained for $10 \mathrm{~d}$ by $C$. cf. neogracile, for $8 \mathrm{~d}$ by F. cylindrus, and for $6 \mathrm{~d}$ by the other 2 species. Slight increases in cell numbers were recorded for all species $2 \mathrm{~d}$ after exponential growth had ceased. Thereafter, cell numbers remained essentially constant, but decreased substantially in F. cylindrus cultures after $t_{16}$.

Biomass increased from an initial value of $1 \mu \mathrm{g} \mathrm{chl}$ a $\left(5 \mu \mathrm{mol}\right.$ POC) $\mathrm{l}^{-1}$ to a peak concentration of about $140 \mu \mathrm{g}$ chl a $\left(850 \mu \mathrm{mol}\right.$ POC) $\mathrm{l}^{-1}$ (Fig 2). Chl a peaked at $t_{12}$, whereas maximum POC concentrations were observed at $t_{1 n}$. Thereafter, chl $a$ as well as POC declined to about $70 \mathrm{\mu g} \mathrm{l}^{-1}$ and $700 \mu \mathrm{mol} \mathrm{l}^{-1}$ respectively at $t_{20}$. The $\delta^{13} \mathrm{C}$ of POC $\left(\delta^{13} \mathrm{C}_{\mathrm{POC}}\right)$ increased from an initial $-24 \%$ to $-9 \%$ at $t_{14}$, and remained essentially constant thereafter. Over the same time interval, $\delta^{13} \mathrm{C}_{\text {DIC }}$ increased to $9.5 \%$. Ratios of $\mathrm{POC} /$ particulate organic nitrogen $(\mathrm{PON})(\mathrm{m} / \mathrm{m})$ and $\mathrm{POC}$ to chl $a(w / w)$ were 6.0 and 62 respectively at $t_{0}$ (data not shown). POC/PON derreaced linearly to 5.0 until $t_{4}$, after which it remained constant. A marked increase of POC/chl a to a value of 120 was observed at $t_{18}$. 


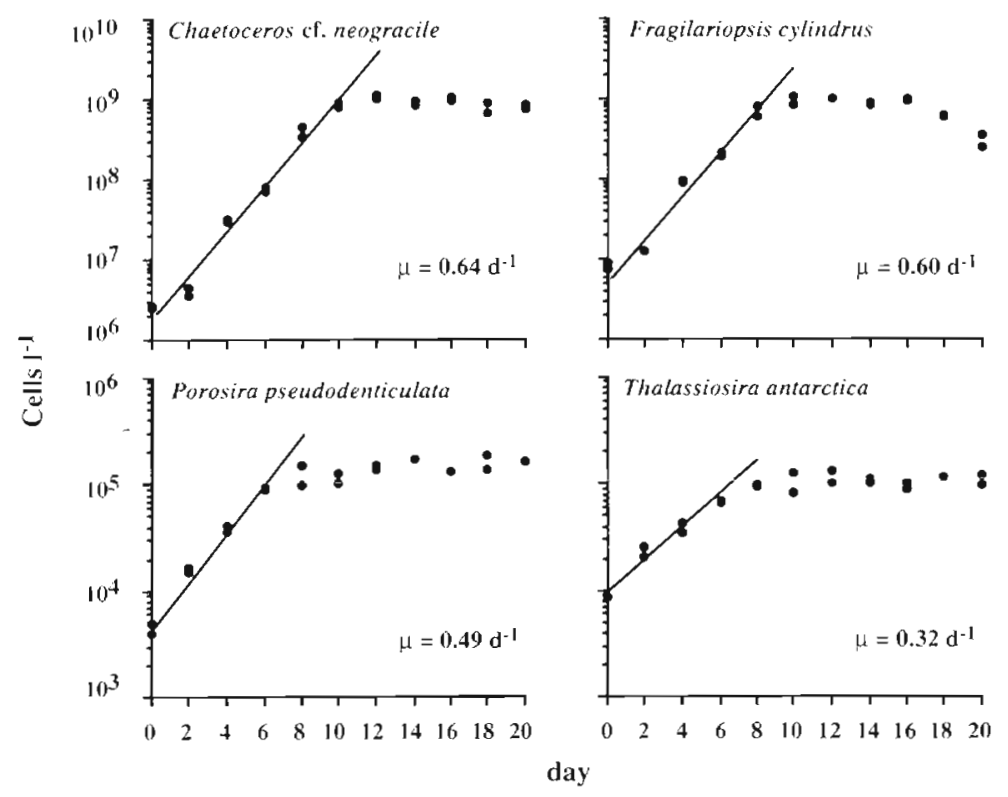

Fig. 1. Cell concentrations of 4 polar diatoms grown in mixed batch cultures at 200 (from $t_{14}$ onwards: 250 ) $\mu$ mol photons $\mathrm{m}^{-2} \mathrm{~s}^{-1}$ and $0^{\circ} \mathrm{C}$ in closed bottle incubations for $20 \mathrm{~d}$. (•) Data points (2 replicates). Solid lines represent best fit of linear regressions during exponential growth. $\mu$ : growth rate

Following resuspension of aliquots into fresh media, an increase in cell numbers was only observed for Chaetoceros cf. neogracile and Porosira pseudodenticulata (Fig. 3). After an initial lag phase, growth rates were similar to those observed in closed bottles early in the experiment $\left(0.65\right.$ and $0.41 \mathrm{~d}^{-1}$ for $C$. cf. neogracile and $P$. pseudodenticulata respectively). No increase in cell numbers was recorded for the other 2 species.

\section{Chemical analyses}

DIC concentrations decreased from $2200 \mu \mathrm{M}$ to 1220 $\mu \mathrm{M}$ at $t_{16}$ (Fig. 4). $\mathrm{CO}_{2}$ (aq) concentrations decreased from the initial $5 \mu \mathrm{M}$ to $<0.01 \mu \mathrm{M}$ at $t_{12}$ (Fig. 5). Oxygen concentrations increased from $310 \mu \mathrm{M}$ to a peak value of $1400 \mu \mathrm{M}$ at $t_{12}$ and declined thereafter to $1200 \mu \mathrm{M}$ at $t_{20}$. Gas bubbles steadily increasing in size were visible in the bottles from $t_{8}$ onwards. The $\mathrm{pH}$ increased from 8.77 at $t_{0}$ to about 10.50 at $t_{16}$, and was slightly lower again at $t_{20}$.

\section{DISCUSSION}

Results obtained in this study demonstrate the physiological capacity of a mixed culture of 4 polar diatoms regularly found in pack ice (albeit with different abundances; Krebs et al. 1987, Garrison \& Buck 1989) to remove about $1000 \mu \mathrm{mol} \mathrm{DIC} \mathrm{\textrm {l } ^ { - 1 }}$ in closed bottle incu- bations before photosynthetic carbon assimilation subsided. In fair agreement with measured DIC depletion, total carbon biomass amounted to about $850 \mu$ mol POC $\mathrm{I}^{-1}$ t the missing 150 umol must have been transferred to dissolved pools. However, growth kinetics (Fig. 1) and different species sizes suggest that $\mathrm{POC}$ production was not alike for each species during the experiment. Following the recommendations given in Edler (1979), we calculated carbon quotas of $2,9,500$ and $2500 \mathrm{pg} \mathrm{C}$ cell ${ }^{-1}$ for Fragilariopsis cylindrus, Chaetoceros cf. neogracile, Thalassiosira antarctica and Porosira pseudodenticulata respectively. Species-specific POC production calculated from cell counts and carbon quotas resulted in peak POC accumulations of d.bout $800,170,30$ and $5 \mu \mathrm{mol}{ }^{-1}$ for $C$. cf.
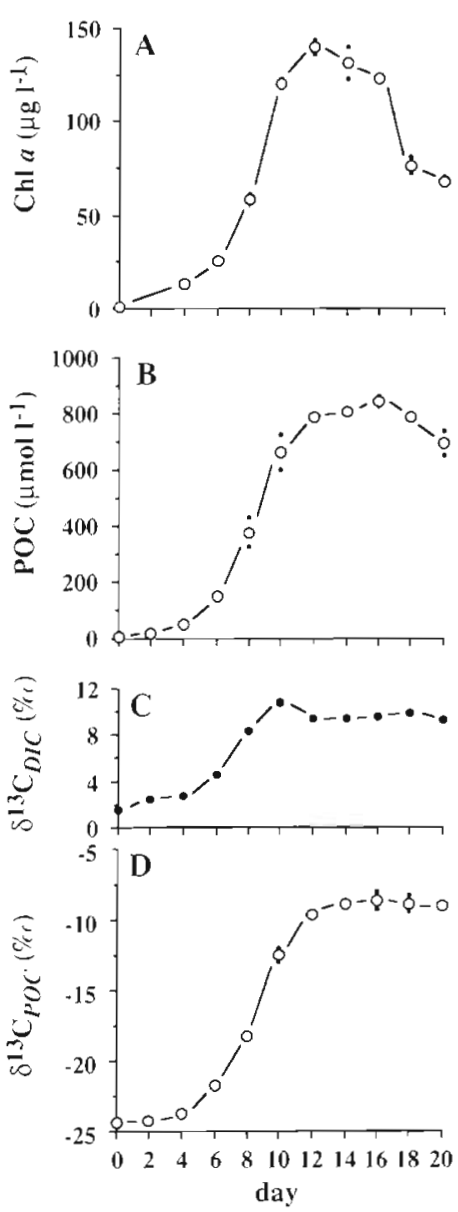

Fig. 2. (A) Chl a and (B) POC concentrations, and isotopic composition of (C) DIC and (D) POC (expressed in $\delta$ notation) in mixed batch cultures of 4 polar diatoms in closed bottle incubations vs experimental period ( $20 \mathrm{~d}$ ). (o) Mean of 2 replicate incubations; $(\bullet)$ data points 


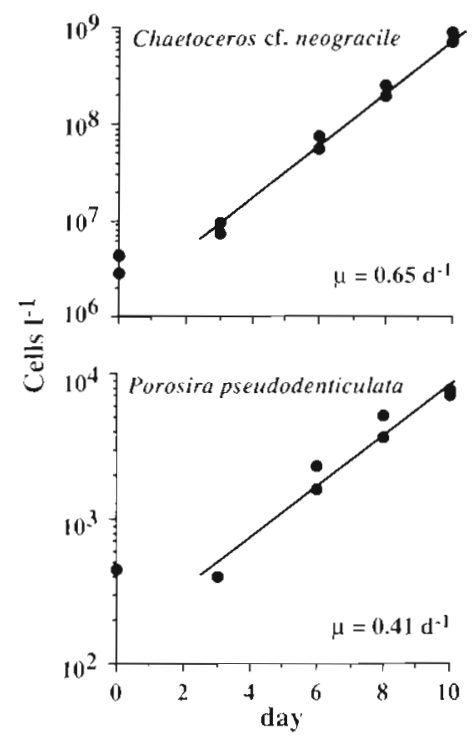

Fig. 3. Cell concentrations of the 2 polar diatoms that grew when resuspended in fresh media following a $20 \mathrm{~d}$ incubation in closed bottles. ( $\bullet$ ) Data points (2 replicates; only 1 replicate was counted at $t_{0}$ and $t_{3}$ for Porosira pseudodenticulata). Solid lines represent best fit of linear regressions during exponential growth. $\mu$ : growth rate
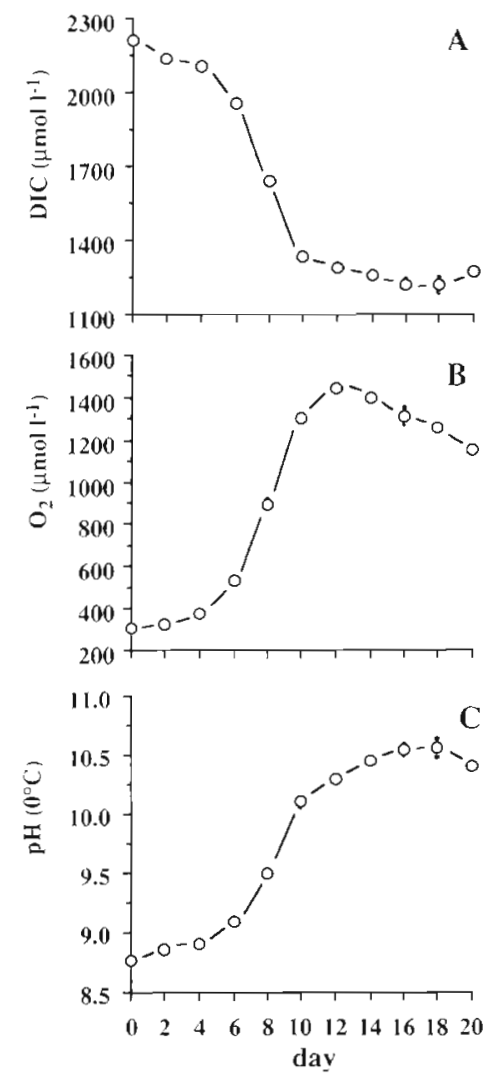

Fig. 4. (A) DIC and (B) $\mathrm{O}_{2}$ concentrations, and (C) pH in mixed batch cultures of 4 polar diatoms grown over $20 \mathrm{~d}$ in closed bottles. Symbols as in Fig. 2

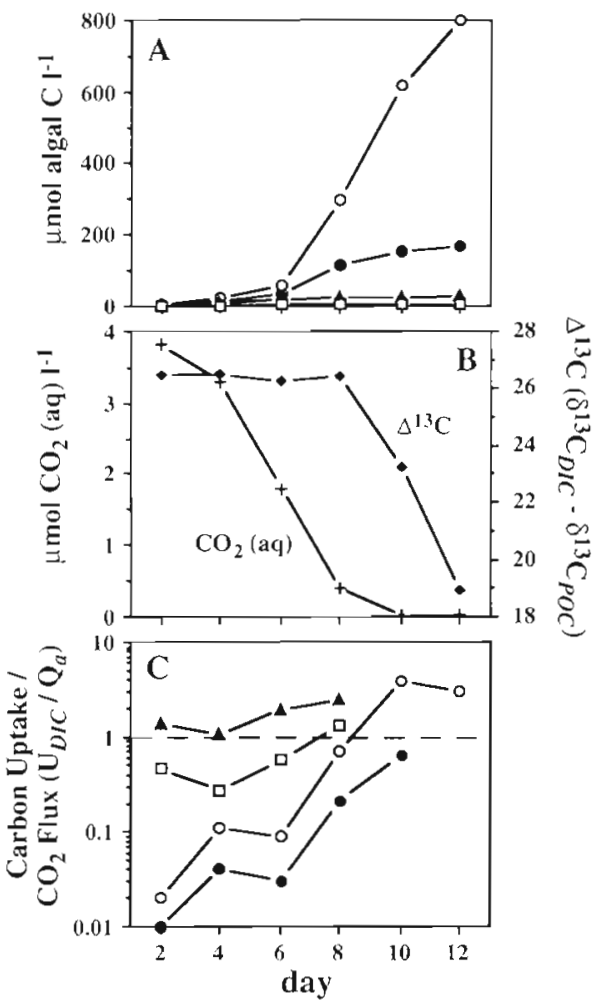

Fig. 5. (A) Algal carbon biomass, determined from cell density and cell quota (see text), (B) changes of $\Delta^{13} \mathrm{C}$ and $\mathrm{CO}_{2}(\mathrm{aq})$ concentration, and $(\mathrm{C})$ ratio of carbon uptake to $\mathrm{CO}_{2}(\mathrm{aq})$ flux between Day 2 and Day 12 of closed bottle incubations (for derivation see text). Symbols in (A) and (C): (O) Chaetoceros cf. neogracile; (•) Fragilariopsis cylindrus; (4) Porosira pseudodenticulata $(\square)$ Thalassiosira antarctica

neogracile, F. cylindrus, $P$. pseudodenticulata and $T$. antarctica respectively, demonstrating that about $80 \%$ of total DIC depletion was due to only 1 , and $>95 \%$ due to growth of only 2 , species.

In brine solutions collected from intact pack ice in the Weddell Sea during summer, Gleitz et al. (1995) measured DIC depletions, oxygen concentrations and $\mathrm{pH}$ values of up to $1200 \mu \mathrm{mol} \mathrm{DIC} \mathrm{kg}{ }^{-1}, 933 \mu \mathrm{mol} \mathrm{\textrm {O } _ { 2 }}$ $\mathrm{kg}^{-1}$ and $\mathrm{pH}$ 9.89. These values are similar to those observed at the end of logarithmic growth in our study, verifying that the concept of the brine channel system being effectively isolated from the surrounding water column for time scales comparable to biological activity (days to weeks) is in fact legitimate. At present, we are not aware of chemical data from undiluted sea ice brine other than the reference cited above, thus it is difficult to evaluate the degree of isolation experienced by internal sea ice communities in nature. From the data presented by Gleitz et al. (1995), we conclude that during summer, brine chemical composition often deviates substantially from conditions found in surface seawater, but may not always attain peak variations as 
observed in this study. This is related to the fact that complete isolation as applied here will not always be maintained under natural conditions for prolonged periods, and some replenishment of dissolved matter within brine channels from the underlying seawater will occur

Nutrient salts were added in excess in this study, and in nature, these will be depleted well before DIC concentrations drop to the levels observed here. Depletion of major nutrients will proceed in parallel to the chemical changes which were of principal concern in the present study (carbonate system, $\mathrm{pH}$, oxygen), but it would be futile to differentiate between effects of the 2 processes on algal growth and survival in an experiment where both were allowed to change to potentially deleterious levels simultaneously. In order to ensure interpretability of the data, we considered it indispensable to avoid nutrient limitation in the experimental set-up, yet we realize that this may somewhat limit our ability to relate our results to the field situation. This, however, will not necessarily invalidate our argument, since sea ice algae have been shown to sustain photosynthesis even after macronutrients were fully depleted ('overflow production'). For instance, in isolated pools of meltwater trapped between brash ice floes in the Weddell Sea in January, Gleitz et al. (1996) measured photosynthetic rates of 3 to $30 \mu \mathrm{g} \mathrm{Cl}{ }^{1} \mathrm{~h}^{-1}$ at nitrate concentrations ranging from undetectable levels to $0.8 \mu \mathrm{mol} \mathrm{^{-1 }}$. The algal assemblages consisted almost entirely of Fragilariopsis cylindrus and Thalassiosira antarctica, and massive accumulation of carbon-rich storage material such as lipid was observed (Fahl \& Kattner 1993). In these samples, pH ranged from 9.07 to 9.29 , and ambient DIC concentrations were depleted by up to $700 \mu_{\mathrm{mol}} \mathrm{l}^{-1}$. Similarly, levels of DIC depletion observed in summer sea ice brine by Gleitz et al. (1995) were explained by sustained carbon assimilation of the internal algal assemblages at exhausted nutrient concentrations.

The sharp decrease in chl $a$ after $t_{12}$ was partly due to decrease of total cell density, but also to bleaching of intact (plasma-containing) cells. Also, empty cells of Fragilariopsis cylindrus were found in substantial numbers ( 30 to $60 \%$ of total cell counts) following $t_{18}$, showing that cell mortality had set in. For the other species, however, only few empty frustules were observed at this time $(<5 \%$ of total cell counts). In our study, only Chaetoceros cf. neogracile and Porosira pseudodenticulata recovered from the experimental treatment and grew when suspended in fresh medium (Fig. 3). Thus, we suspect that deterioration of cell integrity at the end of the summer bloom may significantly influence recolonization of the water colum.n following floe disintegration, provided that sea ice isolation is so effective as to allow environmental conditions to decline to extreme levels. This may have important consequences for species composition of ice-edge blooms, as it may prevent or delay growth of damaged species upon entering the open water

From the data presented here it is difficult to specify factors that eventually caused termination of growth of the different species. It is feasible though to assume that high rates of photorespiration at oxygen oversaturation and strongly alkaline $\mathrm{pH}$ in conjunction with very low $\mathrm{CO}_{2}(\mathrm{aq})$ concentrations were major factors leading to stagnation of cell division. However, as noted above, growth subsided at different times for different species, suggesting a differential tolerance to abiotic variations.

We hypothesize that pathways of DIC acquisition may have been one critical factor determining growth capacity in our experiment. Monitoring carbon isotope fractionation during photosynthesis has helped to elucidate pathways of DIC acquisition in microalgal cultures (e.g Hinga et al. 1994, Laws et al. 1995). For instance, several lines of evidence suggest that the ${ }^{13} \mathrm{C}$ content of marine phytoplankton POC may vary as a function of external $\mathrm{CO}_{2}(\mathrm{aq})$ concentrations as the $\delta^{13} \mathrm{C}_{\mathrm{POC}}$ signal emanating from diffusive $\mathrm{CO}_{2}(\mathrm{aq})$ uptake is modified significantly when ${ }^{13} \mathrm{C}$-enriched $\mathrm{HCO}_{3}^{-}\left(\delta^{13} \mathrm{C}_{\mathrm{HCO}_{3}}{ }^{-}\right.$, ca $11.9 \%$ more positive than $\delta^{13} \mathrm{C}_{\mathrm{CO}_{2}}$ at $0^{\circ} \mathrm{C}_{i}$ Mook et al. 1974) is taken up and/or $\beta$-carboxylations are dominant mechanisms of carbon acquisition (Descolas-Gros \& Fontugne 1990, Raven et al. 1993, Goericke et al. 1994).

Antarctic phytoplankton is generally characterized by low $\delta^{13} \mathrm{C}$ values of -24 to $-35 \%$, possibly the result of high $\mathrm{CO}_{2}(\mathrm{aq})$ concentrations at low sea surface temperatures (Rau et al. 1989, Goericke et al. 1994). On the other hand, higher $\delta^{13} \mathrm{C}$ values of up to $-16.7 \%$ have been observed in the particulate organic matter obtained from sea ice or from waters closely associated with sea ice (Fischer 1991, Rau et al. 1991), which has been related to photosynthetic carbon assimilation taking place under the confined conditions thought to prevail within the brine channel system (Gleitz et al. 1995).

In this study, the isotopic composition of POC increased sharply from -24 to $-9 \%$ during the experiment (Fig. 2). This change was most pronounced between $t_{6}$ and $t_{12}$, when $>90 \%$ of the biomass production (i.e. DIC uptake) was due to growth of only 2 species, Chaetoceros cf. neogracile and Fragilariopsis cylindrus (Fig. 5A). During this time interval, $\mathrm{CO}_{2}$ (aq) decreased substantially to well below $0.01 \mu \mathrm{M}$ (Fig 5B)

In order to ascertain concomitant changes in carbon isotope fractionation, we calculated $\Delta^{13} \mathrm{C}$ by subtracting $\delta^{13} \mathrm{C}_{\text {poc }}$ from $\delta^{13} \mathrm{C}_{\mathrm{DIC}}$ (Rau et al. 1996). This evaluation revealed that whereas the initial increase in 
$\delta^{13} \mathrm{C}_{\text {poc }}$ until $t_{8}$ was apparently related to ${ }^{13} \mathrm{C}$ enrichment of the source DIC (i.e. constant fractionation; Fig. $5 \mathrm{~B}$ ), a profound decrease in $\Delta^{13} \mathrm{C}$ by about $8 \%$ was observed from $t_{8}$ until $t_{12}$ when $\mathrm{CO}_{2}$ (aq) concentrations fell to $<0.5 \mu \mathrm{M}$. In order to clarify if this substantial decrease in fractionation was related to changes in the form of DIC acquisition, we compared photosynthetic carbon uptake $\left(U_{\text {DIC }}\right.$ ) for each individual species with the potential maximum flux of $\mathrm{CO}_{2}(\mathrm{aq})$ to the cell surface $\left(Q_{a}\right)$ for consecutive measuring intervals.

For 3 out of the 4 species tested, our calculations suggest that diffusional $\mathrm{CO}_{2}$ (aq) flux was in fact sufficient to satisfy cellular carbon demand (Fig. 5C). The strong discrimination against ${ }^{13} \mathrm{C}$ at $\mathrm{CO}_{2}(\mathrm{aq})$ concentrations $>0.5 \mu \mathrm{M}$ is well in accord with photosynthesis relying primarily on diffusive $\mathrm{CO}_{2}(\mathrm{aq})$ uptake (Goericke et al. 1994, Rau et al. 1996). Only for the largest species employed (Porosira pseudodenticulata) does direct $\mathrm{HCO}_{3}{ }^{-}$utilization need to be invoked to account for the observed rate of photosynthetic carbon uptake (Fig. 5C). Its contribution to total DIC uptake, however, did not exceed about $20 \%$ until $t_{6}$, when exponential growth of this species subsided. On the other hand, the steep decrease in carbon isotope fractionation between $t_{8}$ and $t_{12}$ coincided with direct $\mathrm{HCO}_{3}{ }^{-}$utilization in Chaetoceros cf. neogracile, exemplified by ratios of $U_{\mathrm{DIC}} / Q_{\mathrm{a}}>1$ (Fig. 5C), which absorbed 70 to $90 \%$ of total DIC after $t_{8}$. Active uptake of $\mathrm{HCO}_{3}{ }^{-}$as opposed to $\mathrm{CO}_{2}(\mathrm{aq})$ diffusion results in a pronounced decrease of discrimination against ${ }^{13} \mathrm{C}$, and hence less negative $\delta^{13} \mathrm{C}$, in microalgae (Sharkey \& Berry 1985). Thus, 2 independent lines of evidence (reduced fractionation against ${ }^{13} \mathrm{C}$ together with photosynthetic carbon demand exceeding diffusional $\mathrm{CO}_{2}$ supply) substantiate the proposed $\mathrm{HCO}_{3}{ }^{-}$utilization in $\mathrm{C}$. cf. neogracile at $\mathrm{CO}_{2}(\mathrm{aq})$ concentrations $<0.5 \mu \mathrm{M}$ and $\mathrm{pH}>9.5$. This interpretation is consistent with the fact that this species has been shown to be a facultative $\mathrm{HCO}_{3}$ user in other experiments using the $\mathrm{pH}$-drift technique (Lützenkirchen pers. comm.).

From these considerations, we infer that the physiological ability to actively assimilate $\mathrm{HCO}_{3}{ }^{-}$at very low $\mathrm{CO}_{2}$ (aq) concentrations may have been a decisive factor explaining the success of Chaetoceros cf. neogracile in our experiments. Induction of DIC concentrating mechanisms at low $\mathrm{CO}_{2}(\mathrm{aq})$ concentrations has been shown to result in less negative $\delta^{13} C_{\text {poc }}$ values in culture experiments with Chlamydomonas reinhardtii (Chlorophyta; Sharkey \& Berry 1985). The ecological significance of active $\mathrm{HCO}_{3}{ }^{-}$uptake is evident from the fact that about $40 \%$ of the total DIC depletion observed in this study occurred after to when C $\mathrm{C}_{2}(\mathrm{arq})$ concentrations decreased to $<0.5 \mu \mathrm{M}$. Yet, it is clear that this physiological feature alone cannot entirely explain the differential. growth patterns observed here, as Porosira pseudodenticulata apparently utilized $\mathrm{HCO}_{3}{ }^{-}$over its entire growth period. Hence, additional factors such as differential tolerance to other environmental constraints (e.g. increasing pH and strong oxygen oversaturation) may have also controlled growth performance. For instance, Hinga et al. (1994) noted that at high $\mathrm{pH}$, it may be difficult for a cell to maintain a given internal $\mathrm{pH}$ when actively transporting charged $\mathrm{HCO}_{3}{ }^{-}$across the cell membrane.

In addition to species-specific mechanisms of carbon acquisition, our data along with the observation that sea ice algal blooms are frequently dominated by small diatoms (Garrison \& Buck 1989) also suggest that small species may gain their competitive edge simply by virtue of favorable surface to volume ratios and outgrow larger species due to their capacity to sustain growth at much lower nutrient (including DIC) concentrations. It is clear though that biotic factors will additionally influence community structure in nature (e.g. composition of seed population, differential grazing pressure etc.). These, however, were beyond the scope of the present investigation.

\section{CONCLUSIONS}

Observations of substantial DIC and nutrient depletion, oxygen oversaturation, strongly alkaline $\mathrm{pH}$ together with ${ }^{13} \mathrm{C}$-enriched POC in samples collected from Antarctic pack ice has prompted several investigators to suggest that the ice habitat may at times resemble a closed system. Our results confirm that polar diatoms have the capacity to bring about levels of DIC depletion, oxygen oversaturation and alkaline $\mathrm{pH}$ as were measured in the field. Moreover, $>95 \%$ of DIC depletion was related to only 2 species with cell volumes $\leq 100 \mu^{3}$, indicating that large species may be diffusion limited at low nutrient and DIC concentrations and do therefore not attain high biomass levels during the spring ice algal bloom. DIC depletion was paralleled by substantial ${ }^{13} \mathrm{C}$ enrichment of POC, suggesting that at $\mathrm{CO}_{2}(\mathrm{aq})$ concentrations $<0.5 \mu \mathrm{M}$, direct utilization of $\mathrm{HCO}_{3}^{-}$was a dominant mechanism of carbon acquisition. Since DIC uptake at such low $\mathrm{CO}_{2}$ (aq) concentrations was almost exclusively due to Chaetoceros cf. neogracile, physiological differences related to pathways of inorganic carbon uptake may be a decisive factor controlling species diversity in sea ice assemblages during bloom maturation. Prolonged confinement of diatoms within sea ice under post-bloom conditions may impair physiological integrity to such an extent as to nrevent growth following release into the open water. We conclude that perturbation of chemical equilibria in sea ice brine in the course of intense biological activity will significantly affect over- 
all productivity of an ice algal assemblage, its community structure, and its biochemical composition as well as its potential to recolonize the water column following ice melt. Thus, biological processes related to the concept of the internal ice habitat being effectively isolated from the surrounding water should be considered as a major variable in future sea ice ecophysiological studies.

Acknowledgements. 110 thank M. Bumann, H. Schwarz and M. Sundermann for supplying the algal isolates. K.-U. Richter provided expert technical assistance during $\delta^{1.3} \mathrm{C}$ measurements. Helpfui comments by D. Wolf-Gladrow and 3 anonymous reviewers are gratefully acknowledged. This is publication no. 1013 of the Alfred Wingener Institute for Polar und Marine Research.

\section{LITERATURE CITED}

Ackley SF, Buck KR, Taquchi S (1979) Standing crop of algae in the sea-ice of the Weddell Sea region. Deep Sea Res 26: $269-281$

Aletsee L, Jahnke J (1992) Growth and productivity of the psychrophilic marine diatoms Thalassiosira antarctica Comber and Nitzschia frigida Grunow in batch cultures at temperatures below the freezing point of seawater. Polar Biol 11:643-647

Almgren T, Dyrssen D, Fonselius S (1983) Determination of alkalinity and total carbonate. In: Grasshoff K, Ehrhardt $M$, Kremling $K$ (eds) Methods of seawater analysis. Verlag Chemie, Weinheim, p 99-123

Clarke DB, Ackley SF (1984) Sea ice structure and biological activity in the Antarctic marginal ice zone. J Geophys Res 89:2087-2095

Descolas-Gros C, Fontugne M (1990) Stable carbon isotope fractionation by marine phytoplankton during photosynthesis. Plant Cell Environ 13:207-218

Dieckmann GS, Lange MA, Ackley SF, Jennings JC Jr (1991) The nutrient status in sea ice of the Weddeli Sea during winter effects of sea ice texture and algae. Polar Biol 11. $449-456$

Edler L (1979) Recommendations on methods for marine biological studies in the Baltıc Sea. Phytoplankton and chlorophyll. Baltic Mar Biol Publ 5, p 38

Evans CA, O'Reilly JE, Thomas JP (1987) A handbook for the measurement of chlorophyll $a$ and primary production. Biological investigations of marıne antarctic systems and stocks (BIOMASS), Vol 8. Texas A\&M University, College Station

Fahl K, Kattner G (1993) Lipid content and fatty acid composition of algal communties in sea-ice and water from the Wedciell Sea (Antarctica). Polar Biol 13:405-409

Fischer. G (1991) Stable carbon isotope ratios of plankton carbon and sinking organic matter from the Atlantic sector of the Southern Ocean. Mar Chem 35:581-596

Garrison DL, Buck KR (1989) The biota of Antarctıc pack ice in the Weddell Sea and Antarctic Peninsula regions. Polar Biol 10:211-219

Garrison DL, Buck KR (1991) Surface-layer sea-ice assemblages in Antarctic pack ice during the austral spring: environmental conditions primary production and com. munity structure. Mar Ecol Prog Ser 75:161-172

Garrison DL, Close AR (1993) Winter ncology of the sea ice biota in Weddell Sea pack ice. Mar Ecol Prog Ser 96:17-31
Garrison DL, Close AR, Gordon LI (1990) Nutrient concentrations in Antarctic pack ice during winter. In: Ackley SF, Weeks WF (eds) Sea ice properties and processes. Proceedings WF Weeks Sea Ice Symposium, CRREL Monogr $90-1$, p $35-40$

Gleitz M, Grossmann S, Scharek R, Smetacek V (1996) Ecology of diatom and bacterial assemblages in water associated with melting summer sea ice in the Weddell Sea, Antarctıca. Antarct Sci (in press)

Gleitz M, Rutgers v. d. Loeff M, Thomas DN, Dieckmann GS, Millero FJ (1995) Comparison of summer and winter inorganic carbon, oxygen and nutrient concentrations in Antarctic sea ice brine Mar Chem 51:81-91

Gleitz M. Thomas DN (1992) Physiological responses of a small Antarctic diatom (Chaetoceros $\mathrm{sp}$.) to simulated environmental constraints associated with sea ice formation. Mar Ecol Prog Ser 88:271-278

Gleitz M. Thomas DN (1993) Variation in phytoplankton standing stock, chemical composition and physiology during sea-ice formation in the southeastern Weddell Sea, Antarctica. J Exp Mar Biol Ecol 173:211-230

Goericke R, Montoya JP. Fry B (1994) Physiology of isotope fractionation in algae and cyanobacteria. In: Lajtha $K$, Michener B (eds) Stable isotopes in ecology. Blackwell Scientific, Boston, p 187-221

Grasshoff K (1983) Determination of oxygen. In: Grasshoff K, Ehrhardt M, Kremling K (eds) Methods of seawater analysis. Verlag Chemie, Weinheim, p 61-72

Hinga KR, Arthur MA, Pilson MEQ, Whitaker D (1994) Carbon isotope fractionation by marine phytoplankton in culture: the effects of $\mathrm{CO}_{2}$ concentration, $\mathrm{pH}$, temperature, and species. Global Biogeochem Cycles 8:91-102

Krebs WN, Lipps JH, Burckle LIf (1987) Ice diatom floras, Arthur Harbor, Antarctica. Polar Biol 7:163-171

Laws EA, Popp BN, Bidigare RR, Kennicutt MC, Macko SA (1995) Dependence of phytoplankton carbon isotopic composition on growth rate and $\left[\mathrm{CO}_{2}\right]_{a q}$; theoretical considerations and experimental results, Geochim Cosmochim Acta 59:1131-1138

Mehrbach C, Culberson CH, Hawley JE, Pytkowicz RM (1973) Measurement of the apparent dissociation constants of carbonic acid in seawater at atmospheric pressure. Limnol Oceanogr 18(6):897-907

Mook WG, Bommerson JC, Staverman WH (1974) Carbon isotope fractionation between dissolved bicarbonate and gaseous carbon dioxide. Earth Planet Sci Lett 22: $169-176$

Palmisano AC, Sullivan CW (1982) Physiology of sea ice diatoms. 1 Response of three polar diatoms to a simulated summer-winter transition. J Phycol 18:489-498

Rau GH, Riebesell U, Wolf-Gladrow D (1996) A model of photosynthetic ${ }^{13} \mathrm{C}$ fractionation by marine phytoplankton based on diffusive molecular $\mathrm{CO}_{2}$ uptake. Mar Ecol Prog Ser 133:275-285

Rau GH, Sullivan CW, Gordon LI (1991) $\delta^{13} \mathrm{C}$ and $\delta^{15} \mathrm{~N}$ variations in Weddell Sea particulate organic matter. Mar Chem 35:355-369

Rau GH, Sweeney RE, Kaplan IR (1982) Plankton ${ }^{13} \mathrm{C}:{ }^{12} \mathrm{C}$ ratio changes with latitude: differences between northern and southern oceans. Deep Sea Res 29:1035-1039

Rau GH, Takahashi T, Des Marais DJ (1989) Latitudinal variations in plankton $\delta^{13} \mathrm{C}$ : implications for $\mathrm{CO}_{2}$ and productivity in past oceans. Nature 341:516-518

Raven JA, Johnston AM, Turpin DH (1993) Influence of changes in $\mathrm{CO}_{2}$ concentration and temperature on marine phytoplankton ${ }^{13} \mathrm{C} /{ }^{12} \mathrm{C}$ ratios: an analysis of possible mechanisms. Global Planet Change 8:1-12 
Riebesell U, Wolf-Gladrow D, Smetacek V (1993) Carbon dioxide limitation of marine phytoplankton growth rates. Nature 361:249-251

Sharkey TD, Berry JA (1985) Carbon isotope fractionation of algae as influenced by an inducible $\mathrm{CO}_{2}$ concentrating mechanism. In: Lucas WJ, Berry JA (eds) Inorganic carbon uptake by aquatic photosynthetic organisms. American Society of Plant Physiologists, p 389-401

This article was submitted to the editor
Utermöhl H (1958) Zur Vervollkommnung der quantitatıven Phytoplankton-Methodik. Mitt Int Verein Theor Angew Limnol 9:1-38

Von Stosch HA, Drebes G (1964) Entwicklungsgeschichtliche Untersuchungen an zentrischen Diatomeen IV. Die Planktondiatomee Stephanopyxis turris, ihre Behandlung und Entwicklungsgeschichte. Helgolander Wiss Meeresunters $11: 209-257$

Manuscript first received: November 6, 1995 Revised version accepted: January 8, 1996 